\title{
CLASS AND SOCIAL INEQUALITY IN IAN MCEWAN'S ATONEMENT
}

\author{
Vasko Talevski \\ Center for Foreign Languages Filos, Skopje \\ talevskivasko@yahoo.com
}

Atonement, perhaps Ian McEwan's best-known novel, is considered an epic of British postmodernist literature because it touches on a variety of contemporary topics. Although Atonement focuses primarily on themes such as love and repentance, it also deals with social class, status, and power, which are analysed in this paper. Furthermore, social stratification and inequality form the crux of this analysis. Using Max Weber's theory of social stratification, and the characters as examples, this research considers how much social division truly exists in the novel, which serves as a mirror to British society. Moreover, various forms of social mobility are examined, as well as the solutions to those problems which are not only present in fiction, but also in reality. Ian McEwan's Atonement talks about these issues and more, he sets problems and poses questions that challenge our lives' perspectives, hence making it a unique literary gem.

Keywords: social class, stratification, inequality, atonement, sociology 


\title{
СОЦИЈАЛНИТЕ КЛАСИ И НЕЕДНАКВОСТА ВО РОМАНОТ ИСКУПУВАЊЕ ОД ИЈАН МЕКЈУАН
}

\author{
Васко Талевски \\ Центар за странски јазици „Филос“, Скопје \\ talevskivasko@yahoo.com
}

Искуйување, можеби најпознатиот роман од Ијан Мекјуан, се смета за ремек-дело на британската постмодернистичка литература, зашто обработува разни современи теми. Иако романот Искуйување првично се фокусира на теми какви што се љубовта и покајувањето, тој, исто така, ги анализира и социјалните класи, како и статусот и моќта што се предмет на интерес во оваа студија. Покрај овие теми, општествената стратификација и нееднаквоста се обработуваат и ја формираат сржта на оваа анализа. Користејќи ја теоријата за општествената стратификација на Макс Вебер и ликовите како примери, оваа студија дава осврт на социјалната поделба во романот, која служи како огледало на реалноста во британското општество. Исто така, анализирани се разни форми на општествена мобилност, како и решенија за овие проблеми, кои се присутни не само во реалноста туку и во фикцијата. Романот Искуйување од Ијан Мекјуан дава осврт на овие проблематики, но, исто така, поставува предизвици и прашања што ги брануваат нашите гледишта, со што го прават овој роман вистинско книжевно ремек-дело.

Клучни зборови: социјални класи, стратификација, нееднаквост, покајување, социологија 


\section{Introduction}

In Ian McEwan's Atonement the central themes are love and repentance, that is, the need to respond to and atone for a crime committed. Besides dealing with topics such as love and atonement, this novel considers social class, status, and power. It examines stratification and inequality - how the British class system can cruelly divide and separate people.

All of this is shown through the characters of Atonement. This is why this paper takes a sociological approach to a literary analysis. Moreover, it explains class according to Max Weber's theory on social stratification, backed by research from various authors, and shows how the characters of the novel embody their surroundings according to this theory. Social mobility is also explained; namely how it works and what kinds of social mobility exist. Talking about class, one cannot but mention the difference and relationship between the rich and the poor. Thus, this paper considers both ends of the spectrum, and illustrates the power system in Britain as reflected in the novel. Whilst this paper deals primarily with class divisions, it also shows how class differences can be overcome. This primarily starts with the novel's title - Atonement. Ian McEwan is such an influential writer because not only does he portray British society with all its flaws, but also shows us the ways in which it is possible to surpass these differences, and atonement is one way class can be breached and made irrelevant. Most, if not all, of the issues mentioned here are dealt with in the novel. The characters are a means to bring forth these issues and also they are the ones who show us how to deal with them and overcome them. For these reasons, the paper focuses its analysis on class through the characters, and it is through them that this research demonstrates the class and social inequality in Atonement. Additionally, the paper not only exposes class challenges, but shows how they have originated, and how through the character's actions, they can be overcome.

\section{Max Weber's Theory of Social Stratification}

The main conflict in the novel sets the scene for this research. It gives us the problem, and opens the door for our sociological analysis of class. However, before any examples from the novel are fully considered, the concepts of class, status, and power need to be explained. These concepts are present in Max Weber's sociological research. Weber was a German sociologist, and was considered one of its founders. He proposed that there are three parts to stratification: class, status, and power. This distinction is referenced in Frank Parkin's work Max Weber, Revised Edition (2002):

In his brief and celebrated treatise on social stratification Weber identifies three 'phenomena of the distribution of power within a community': classes, status groups and parties. Each of these represents a distinct aspect of power in so far as each constitutes a different basis for staking claims to material and symbolic 
rewards. The three dimensions or phenomena of power are said to stand in some definite relationship to one another in the stratification order (Parkin 2002: 90).

To get a better grasp of Weber's social stratification, this section is going to focus on these distinctions of power. Weber originally approached the concept of power from the point of view of command and control. This is important to this study as the characters in the novel impose their will through the social constructs that power commands. In his seminal work The Theory of Social and Economic Organization (1947) $)^{1}$ Weber wrote that power is "highly comprehensive from the point of view of sociology. All conceivable qualities of a person and all conceivable combinations of circumstances may put him in a position to impose his will in a given situation" (Weber 1947: 153). This tells us that any and all commands by people in power will be obeyed, as is the case in the novel with characters from the upper class. Further, Weber defined class as social construct in which the provision of goods, external life situations and subjective satisfaction or frustration influence this category. He said that:

These probabilities define class status in so far as they are dependent on the kind and extent of control or lack of it which the individual has over goods or services and existing possibilities of their exploitation for the attainment of income or receipts within a given economic order (ibid., 424).

Moreover, Weber equated the final category status to that of social prestige:

The term of 'social status' will be applied to a typically effective claim to positive or negative privilege with respect to social prestige so far as it rests on one or more of the following bases: (a) mode of living, (b) a formal process of education which may consist in empirical or rational training and the acquisition of the corresponding modes of life, or (c) on the prestige of birth, or of an occupation (ibid., 428).

This theory of social stratification by Max Weber is going to be shown in the following section through an analysis of the characters and the social situations in the novel.

\subsection{Class status}

In terms of the first facet of stratification - class, it is essential to distinguish the different types of class. First, we have the upper class, or the rich who live off property wealth and enjoy all the commodities of life. Then we have the lower class, which refers to those who don't have any property wealth and rarely have access to material resources. In Social Class and Stratification (1990), Peter Saunders gives a brief summary of Weber's views on class:

The upper class consists of those who live off property income and enjoy the privileges of education. The lower class, by contrast, is 'negatively privileged'

\footnotetext{
${ }^{1}$ The original work by Max Weber Economy and Society was published in 1921-1922.
} 
on both dimensions. They neither own resources which can be used to generate revenue, nor do they have the education which could bring them a high salary (Saunders 1990: 22-23).

Between these two ends of the class spectrum are the middle and working classes. The main difference between these two categories is that the working classes occupy jobs that don't require high education. Moreover, it is worth saying that the middle class is such a broad term that today we distinguish two types of middle class - upper middle class and lower middle class. In her book A Contemporary Approach To Race, Class, and Gender (2012), Lisa A. Keister describes the middle and working class by saying:

Between the two extremes are the middle class and the working class. The middle and working classes are somewhat more difficult to distinguish; but, again they tend to be groups that are similar in the types of jobs they do and the resources they control. Compared with the middle class, members of the working class tend to occupy lower-skilled jobs that require less education and generate lower incomes (Keister 2012: 20).

\subsection{Social status}

The second facet of stratification, according to Weber, is status. He believed that status is different from class, in that status refers to the lifestyles people have. Weber says that 'A social 'stratum' stand is a plurality of individuals who, within a larger group, enjoy a particular kind and level of prestige by virtue of their position and possibly also claim certain special monopolies" (Weber 1947: 428-429). This of course refers to whether people of class use their position to take the full advantage that their class provides. Weber used this notion of lifestyle to explain the styles of life of a specific status group. In her research on class, Keister reaffirms Weber's views on status by writing:

Status is the honor, prestige, or respect that certain people possess because of their lifestyle. Whereas class comes from people's relations to production, status comes from their consumption, culture, social interests, and other elements of their lifestyle (Keister 2012: 69).

\subsection{Power}

The third part of stratification is - power. This, according to Weber, refers to the political position one holds, and the influence carried with it. Keister in her research writes:

Party or power refers to a person's position relative to established bureaucratic organizations whose goal it is to influence a type of collective action. For example, a position in a formal political organization or another political party, a labor union, a professional association, an ethnic group, a business group, or a related organization confers a degree of power (ibid., 71). 
All of the above mentioned stratification aspects are relevant to this analysis because they help define the social division and inequality present in Atonement, and also with these concepts the characters' roles are more easily explained. Thus, since the class concepts have been defined, the analysis will now centre on a more specific consideration of individual characters. A short summary of the novel will help set the scene for a deep analysis of social class.

\section{Class and social inequality in Ian McEwan's Atonement}

Atonement is a novel, in which, a young girl, Briony Tallis, uses her vivid imagination to misinterpret the adult world of her countryside surroundings, which in turn divides her family, enrages her sister Cecilia, and puts Robbie Turner behind bars. Briony claimed that she had seen how Robbie had sexually attacked her cousin Lola, when in fact, it was Paul Marshall who had committed this crime, who in a weird twist of events, ends up marrying his victim Lola. This Pandora's box of damning lies and cruel truths opens the door to this sociological research involving class.

In terms of class, the analysis is firstly going to centre on the upper class, which in this novel refers to Paul Marshall, the main culprit in Atonement. He is the perpetrator, however, he doesn't suffer any consequences, nor is he ever considered a suspect. This is the result of the class system that exists in Atonement, where the rich are guiltless and the poor are the ones to blame. This is why, for example, all in the Tallis family except Cecilia cast their doubts on Robbie rather than Marshall. This is highlighted in Megan Halford's paper 'Pass the Amo!': Metonymy and Class in Ian McEwan's Atonement (2012) where she writes:

Although Robbie Turner, son of the Tallis family's charlady, and Paul Marshall, 'the chocolate millionaire', engage in analogous sexual encounters in 'Part One,' the Amo bar and the wealth it represents distinguish them from each other by making Paul, in his position of relative power, appear to be above suspicion for raping Lola and by casting doubt on working-class Robbie (Halford 2012: 1).

Paul Marshall is a soon to be chocolate magnate, in a similar class position to the Tallis family. They both represent the newly rich who had made their fortune by taking advantage of the opportunities offered by capitalist society. The Tallises had built their wealth by selling locks. This is also stated in Julie Ellam's Ian McEwan's Atonement (2009) where she explains the Tallises' wealth as she writes:

We are told how it was acquired by the grandfather who made his money in locks and was intended to be a demonstration of his wealth. This money has also allowed the Tallises to be raised into the upper ranks of the class system... (Ellam 2009: 47).

In Atonement, the same fate is expected for Paul Marshall. He is going to use the Second World War to make his riches by selling chocolate to the army troops fighting abroad. This capitalist system is described by Kath Woodward in her book Questioning Identity: Gender, Class, Ethnicity (2004) where she writes that capitalism is: "A system driven by the investment of private capital in large-scale production activities in pursuit of private profit" (Woodward 2004: 95). Hence, with both 
families, the Tallises and Marshalls, having similar backgrounds it is unsurprising that Paul Marshall was not blamed for his transgressions. Actually, in reading the novel, it is clear that Emily Tallis held an underlying hostility towards Robbie, and so it was quite easy for her to blindly blame him for something he hadn't done. She was against him from the start, ever since her husband Jack took Robbie and his mother Grace under his wing. Jack Tallis's decision to finance Robbie's education was something that Emily thought was unfair to their own children:

\begin{abstract}
She liked him well enough, and was pleased for Grace Turner that he had turned out to be bright. But really, he was a hobby of Jack's, living proof of some levelling principle he had pursued through the years. When he spoke about Robbie, which wasn't often, it was with a touch of self-righteous vindication. Something had been established which Emily took to be a criticism of herself. She had opposed Jack when he proposed paying for the boy's education, which smacked of meddling to her, and unfair on Leon and the girls...Robbie's elevation. 'Nothing good will come of it' was the phrase she often used, to which Jack would respond smugly that plenty of good had come already (McEwan 2002: 89).
\end{abstract}

Her view was further exacerbated when she found out that Robbie had decided to go to medical college and that Jack was the one who was going to pay for it: "She described the dinner, and Robbie's wild look at the table. 'Do we really need to be putting him through medical college?' 'We do. It's a bold move. Typical of him. I know he'll make a go of it'" (ibid., 90).

With this we learn that although Robbie comes from a working-class family, he had the education and thus, status of an upper-class family. This enabled him to breach the class system in Atonement. Max Weber writes about the fluidity of class: "Transitions from one class status to another vary greatly in fluidity and in the ease with which an individual can enter the class. Hence the unity of 'social' classes is highly relative and variable." (Weber 1947:425). However, regardless of his high status, Robbie couldn't manage to persuade everyone that it was not him who had attacked Lola. This came down to the fact that Robbie was not in the same class as Marshall, since he did not possess the same wealth as Marshall. Magan Halford backs this view by saying that "It is ultimately Paul's money and Robbie's lack thereof, rather than the decency of their actions or the refinement of their manners, that cause the Tallises to treat the two men differently" (Halford 2012: 1). Hence, we have Emily's sulky behaviour. Moreover, she even encouraged Briony in her lies that fateful night, which is also used as an example in Brian Finney's paper Briony's Stand Against Oblivion: The Making of Fiction in Ian McEwan's Atonement (2004):

The result is Emily's encouragement of Briony in her childish lie. As Cecilia writes to Robbie in France: 'I'm beginning to understand the snobbery that lay behind their stupidity. My mother never forgave you your first (class degree)' (Finney 2004: 196).

These views on class were present even in Briony's thinking, who as a child was highly influenced by her family's upper-class snobbery. In her paper on Atonement, Megan Halford points out the underlying theme of discrimination present in Briony: 
Even Briony, in her childhood naiveté, knows that a relationship between Robbie and her sister would be one that 'leaps across boundaries', and McEwan's depiction of class shows what a difficult, if not impossible, leap it is to make (Halford 2012: 7).

The impossible relationship in Atonement is the one between Cecilia Tallis and Robbie Turner. Their relationship breaks all boundaries, but it is also the one which shows how much class division there really is in the novel. The class differences can be seen from the start. Their awkward interactions are the result of class differences, which account for their misunderstandings:

Two days before he had rung the front doorbell - in itself odd, for he had always had the freedom of the house. When she was called down, he was standing outside asking in a loud, impersonal voice if he could borrow a book. As it happened, Polly was on all fours, washing the tiles in the entrance hall. Robbie made a great show of removing his boots which weren't dirty at all, and then as an afterthought, took his socks off as well, and tiptoed with comic, exaggeration across the wet floor (McEwan 2002: 17).

If this had been Paul Marshall or somebody of his status, they wouldn't have bothered to keep an appearance. Cecilia believed that this was Robbie's way of distancing himself; that he had exaggerated, when in fact the misunderstandings were due to the class system. Further examples of this can be found in their interactions about funding his medical pursuits, "'Look, I've agreed to pay your father back. That's the agreement.' 'That's not what I meant at all."' (ibid., 17). Reading this we can state that money was definitely an obstacle that emphasized their differences and made their relationship difficult. Thus, we can establish that the reason for them taking so long to realise their love and come together was due to the awkward misinterpretations caused by the class system. This is why it took so long for them to admit that they loved each other. However, after Robbie was sentenced to prison, their love could be seen only through their correspondence. This is where we could see how Robbie truly elevated his status to that of Cecilia. The working-class were thought not to have any considerable education, but in this case, it was Robbie's education, or rather his education in literature that opened up a whole new world around him. A world where he could aspire to something better, something that his mother didn't have. In her paper The Complexity of Class: A Study of Ideology and the Power of Literature in Ian McEwan's Narrative (2009) Carolina Carlbom writes about the effect literature has:

In Atonement, Robbie Turner liberates his mind through literature and this enables him to make 'his own decisions' about his aspirations in life. Literature also serves as something that will make him a better human and more skilful in his medical practice (Carlbom 2009: 93).

Moreover, it was literature that made them equal, and gave them a way to express their love:

So they wrote about literature, and used characters as codes. At Cambridge, they had passed each other in the street. All those books, those happy or tragic couples 
they had never met to discuss! Tristan and Isolde, the Duke Orsino and Olivia (and Malvolio too), Troilus and Criseyde, Mr. Knightly and Emma, Venus and Adonis. Turner and Tallis. Once, in despair, he referred to Prometheus, chained to a rock, his liver devoured in a library 'was a code for sexual ecstasy' (McEwan 2002: 118).

Besides being a love story that breaks all boundaries, and worthy of that of Romeo and Juliet, theirs was also a love story of social mobility. Their relationship is a perfect example of how class mobility works in the novel, and the kinds of social mobility present.

Lisa A. Keister explains social mobility as a:

change in social status over time, for either an individual or an entire group. Mobility can be measured across generations (i.e., a change in status in a person's own life). It refers to movement up and down various social hierarchies, including income, wealth, education, and occupation. Social mobility refers to both upward and downward mobility; that is, some people achieve more than their parents, others achieve less (Keister 2012: 295).

Robbie Turner is probably the best example of upward social mobility. As was mentioned previously, Robbie comes from a working-class family, but possesses the status of an upper-class family. His position in society is quite different to that of his mother. This kind of social mobility is called intergenerational mobility which according to Lisa A. Keister refers to "movement between generations" (ibid., 296). Robbie's education opened up a new world of opportunities to him. Moreover, as Ian Fraser states in his essay Class Experience in Atonement (2013): "children who receive the education their parents did not are set on a path of cultural dislocation" (Fraser 2013: 2). Obvious examples of this are present in the novel when Robbie interacts with his army buddies on their way to Dunkirk. His friends could not believe that a soldier of his rank could express himself in the way he did, which was in a way representative of an upper-class person, and distinguished himself from his blue-colour friends, "On the first night, when they were sheltering in the bike shed of a burned-out school, Corporal Nettle said, 'What's a private soldier like you doing talking like a toff?'” (McEwan 2002: 111). The illustrations confirm the postulate that Robbie is an example of upward social mobility.

However, on the other hand, we have the Tallis sisters who in their atonement also change their social class. The Tallis sisters come from a rich family, but instead of pursuing a position typical of their class, they try to remedy their mistakes by working in a blue-colour profession as nurses. This is especially true of Briony Tallis who did the most harm with her vivid imagination. Briony tries to atone for her mistake by abandoning her Cambridge education and instead pursuing a career as a nurse to get closer to Cecilia and Robbie:

The first surprise is that Briony isn't at Cambridge. She didn't go up last autumn, she didn't take her place. I was amazed because I'd heard from Dr. Hall that she was expected. The other surprise is that she's doing nurse's training at my old hospital (ibid., 122). 
Both sisters represent in their own way downward social mobility. In his paper on class Ian Frasier states that:

Cecilia has turned her back on her upper-middle-class background and identifies her interests with Robbie against the interests of her family, admittedly all through the meditation of love, but it does involve a fracturing of her previous consciousness that accepted the established hierarchical order of class society...Consequently, Cecilia does not speak to her parents, brother, or sister again once Robbie is sent to prison. Overall, then, we can see how the class experience develops into class consciousness for Cecilia on the microcosmic level (Frasier 2013: 8-9)

Class consciousness is exactly the antidote to class division and inequality. This is one of the ideas that Ian McEwan tries to promote in Atonement. It is precisely social awareness and atonement that break the social boundaries in his novel. This is what some of the characters in the novel try to do, or to be more precise, this is exactly what the Tallis sisters and Robbie try to do to break the social norms which society had tried to impose on them. However, class consciousness doesn't come without struggle. It is by fighting the established class norms that one can break the social boundaries to breach division and inequality. In Atonement, Ian McEwan uses literature as a way to demonstrate sympathy and to pave the path for overcoming class differences. In addition, literature can help bridge the gap between people, and thus create a community. Even though Briony, Cecilia and Robbie become class conscious and overcome these obstacles, they did not accomplish this without mistakes and doubts of their own. When Briony told Cecilia and Robbie that it was Marshall, and not Danny Hardman who raped Lola, they could not believe this, they were flabbergasted:

'And if you can remember anything at all about Danny Hardman, where he was, what he was doing, at what time, who else saw him - anything that might put his alibi in question, then we want to hear it'... Briony stood too and said, 'Old Hardman was probably telling the truth. Danny was with him all that night'...'It was Paul Marshall' (McEwan 2002: 202-203).

This shows that class division and discrimination were deeply rooted even in those who wanted to eliminate it. However, what Ian McEwan is trying to tell us is that it is only through trying, failing, and trying again that one can right the wrongs, and atone for the sins in his life, whether they be class related or otherwise. With this message he ends his novel:

The problem these fifty-nine years has been this: how can a novelist achieve atonement when, with her absolute power of deciding outcomes, she is also God? There is no one, no entity or higher form that she can appeal to, or be reconciled with, or that can forgive her. There is nothing outside her. In her imagination she has set the limits and the terms. No atonement for God, or novelists, even if they are atheists. It was always an impossible task, and that was precisely the point. The attempt was all (ibid., 217). 
This extract shows Briony's attempt for atonement. The denouement finally reveals that Briony was the author of the story and that this was her imagination or rather her attempt for a fictional reconciliation with both Robbie and Cecilia. Moreover, the passage shows that since the main characters have long been dead, a real reconciliation is not possible. Hence, the story Atonement, written by Briony is a confession or atonement for her past mistakes. Evoking God here means that one cannot self-ascribe atonement, but that forgiveness needs to be given. This further affirms McEwan's point that it is only the attempt that matters. Briony tries to reflect and reshape the narrative in order to give happiness to Robbie and Cecilia, even though this did not spare her of her actions. Thus, it is by trying to right the wrongs that one can achieve atonement and live with their past mistakes. Near the end of the novel, Ian McEwan makes a reference to contemporary British society. On her way back to her former home, Briony is driven in a cab by a West Indian driver whom she misjudges. She is surprised by his education; since somebody of his descent was not known to be highly educated in Britain. Briony reminisces about this encounter:

It was a dusty minicab, whose rear seat was covered in nylon fur with a zebra pattern. But the driver, Michael, was a cheerful West Indian lad who took my case and made a fuss of sliding the front passenger seat forward for me ... He had never known his father, and his mother was a doctor at the Middlesex Hospital. He himself graduated in law from Leicester university, and now he was going to the LSE to write a doctoral thesis on law and poverty in the third world....It is quite impossible these days to assume anything about people's educational level from the way they talk or dress or from their taste in music. Safest to treat everyone you meet as a distinguished intellectual (ibid., 211-212).

These passages show us how society has changed from when Briony was a young girl in a time of segregation and discrimination to a new reality where we have a more equal society accepting of various cultures and people. It also hints at globalisation and the complexity of status in contemporary society. Briony learns that the modern world has opened up new doors that previously had not existed. Now, all walks of all can have a chance at an education, and reach a status that their parents simply could not. Carolina Carlbom writes that "Globalization has led to a different kind of society. We live in a world of ethnic diversity, mixed cultures and new values" (Carlbom 2009: 5). However, even though progress has been achieved, it must not be forgotten that for class equality to be achieved, one must always try to improve oneself and the others around him; one must try to treat others as equals, as they would want to be treated. Ian McEwan conveys this message in Atonement, and his ideas are backed up by Brian Finney's comments: "the attempt to imagine the feelings of others is perhaps the one corrective that we can make in the face of continuing human suffering" (ibid., 16). In the same paper Carolina Carlbom goes on to say that "the ability of imagining other people's situations and perspectives could be an important tool for understanding the world as well as for evolving on a personal level" (ibid., 16). This is exactly what literature allows you to do; exactly what literature allowed Ian McEwan to do, and what he allowed his characters Briony, Cecilia and Robbie to do - to understand what it means to be a human being. 


\section{Conclusion}

This paper illustrates the class and social divisions present in Ian McEwan's novel. Atonement shows how class and social mobility work in a highly divisive society. He showed that although there is an opportunity to breach and eliminate class, it does not mean that class society in itself has disappeared. In Atonement, the rich and powerful present themselves as upstanding citizens while they dump their morally corrupt souls into the backyards of poor people. In the novel, Paul Marshall never gets prosecuted for his crimes, and in a mind-blowing twist ends up marrying his victim Lola. The poor - such as the Hardmans - are always first to blame, and the likes of Robbie never get a break, and are sent to prison. Robbie and Cecilia are constantly separated by the class system, but in the end, Briony atones for her mistakes by unifying them in eternal love. McEwan shows us that social stratification still exists, but that it is through compassion and sympathy that people can breach the divides, and eventually break free of the social boundaries imposed by society. That is why Max Weber's theory of social stratification is is still relevant today. Social divisions still exist in society and dictate everyday life. By reading his findings one can understand the complex social constructs and apply this knowledge to better understand other people and to overcome any social divisions.

\section{References}

Ellam, J. (2009). Ian McEwan's Atonement. London: Continuum.

Keister, L. (2012). Inequality: A Contemporary Approach to Race, Class, and Gender. New York: Cambridge University Press.

McEwan, I. (2002). Atonement. New York: Doubleday.

Parkin, F. (2002). Max Weber Revised Edition. London: Routledge.

Saunders, P. (1990). Social Class and Stratification. London: Routledge.

Weber, M. (1947). The Theory of Social and Economic Organization. New York: Oxford University Press.

Woodward, K. (2004). Questioning Identity: Gender, Class, Ethnicity. London: Routledge.

Carlbom, C. (2009). The Complexity of Class - A study of Ideology and the Power of Literature in Ian McEwan's Narrative. [Online] BA Thesis. K01 Literary Seminar, Lund, 2009, Lund University. Available from: http://lup.lub.lu.se/student-papers/ record/1415099 [Accessed: August, 13th, 2019]

Finney, B. (2004). Briony's Stand against Oblivion: The Making of Fiction in Ian McEwan's Atonement. [Online] Journal of Modern Literature, 27 (3):68-82. Available from: https://www.jstor.org/stable/3831941? read-now=1\&seq=1\#metadata info tab contents [Accessed: September 17th, 2019]

Fraser, I. (2013). Class Experience in Atonement. [Online] Critique: Studies in Contemporary Fiction, 54(4): 465-477. Available from https://www.tandfonline.com/doi/abs/10.1080/ 00111619.2012.656208 [Accessed: September 20th, 2019]

Halford, M. (2012). "Pass the Amo!": Metonymy and Class in Ian McEwan's Atonement. [Online] The Albatross, 2(1):25-32. Available from: https://journals.uvic.ca/index.php/ albatross/article/view/10452 [Accessed: August 19th, 2019] 